\title{
Katarzyna Krysińska-Kościańska
}

Uniwersytet Ekonomiczny we Wrocławiu

e-mail: katarzyna.krysinska-koscianska@ue.wroc.pl

\section{RÓŻNORODNOŚĆ ZE WZGLĘDU NA PLEĆ - BARIERY AWANSU KIEROWNICZEGO KOBIET}

\section{GENDER DIVERSITY: BARRIERS OF THE WOMEN'S PROMOTION}

DOI: $10.15611 /$ pn.2018.512.09

JEL Classification: J16

Streszczenie: Problematyka różnorodności pracowników jest jednym z ważniejszych wyzwań w dzisiejszych organizacjach. Pozytywny potencjał różnorodności jest dostrzegany pomimo istniejących barier. Zarządzanie różnorodnością może być rozpatrywane $\mathrm{w}$ wielu aspektach. Niniejszy artykuł poświęcony jest wymiarowi płci w miejscu pracy. Jego celem jest opisanie wspomnianych barier na podstawie przeprowadzonych studiów literaturowych oraz studium przypadku, a także przedstawienie możliwych rozwiązań mogących zachęcić kobiety do odgrywania ról kierowniczych w organizacjach.

Słowa kluczowe: różnorodność ze względu na płeć, kobiety w zarządzaniu, bariery awansu, luka płacowa.

Summary: The issue of diversity of employees is one of the most important challenges in today's organizations. The positive potential of diversity is noticed despite the existing barriers. Diversity management can be considered in many aspects. This article is devoted to the gender dimension in the workplace. Its purpose is to describe the aforementioned barriers on the basis of literature studies and a case study, as well as to present possible solutions that may encourage women to perform managerial roles in organizations.

Keywords: gender diversity, women in management, barriers to promotion, pay gap.

\section{Wstęp}

Dynamika procesów zachodzących w wielu obszarach globalnego rynku ostatniej dekady, a zwłaszcza zmiany polityczne, postęp technologiczny, rosnąca mobilność międzynarodowa, zmiany demograficzne oraz zmiany społeczne, są bezpośrednimi przyczynami rosnącej różnorodności współczesnych społeczeństw. 
Różnorodność jest przedmiotem analiz różnych dziedzin i dyscyplin naukowych. W naukach o zarządzaniu problematyka ta jest podejmowana w kontekście zarządzania zasobami ludzkimi (ZZL) oraz wskazywana jako najważniejszy trend XXI wieku [Hasson Barrett 2012], strategiczne wyzwanie dla funkcji personalnej [Besler, Sezerel 2012]. Niektórzy autorzy zarządzanie różnorodnością pracowników w jej wielu innych wymiarach (m.in. rasy, religii, etniczności, zajmowanego stanowiska, wykształcenia, wyglądu, sytuacji materialnej) określają jako wyższe stadium rozwoju ZZL [Wziątek-Staśko 2012].

Problematyka różnorodności pracowników jest najważniejszym wyzwaniem dla działań personalnych [Besler, Sezerel 2012; Dzieńdziora 2017], wymaga bowiem proaktywnej minimalizacji zagrożeń, które niesie ze sobą brak homogeniczności [Krawczyk-Bryłka, Stankiewicz 2014], i decyduje o przewadze konkurencyjnej [Christiansen, Sezerel 2013; Ricco, Guerci 2014].

Wielu badaczy zwraca uwagę, że na znaczeniu coraz bardziej zyskuje wymiar płci [Kupczyk 2013]. Zauważa się rosnącą popularność ruchów emancypacyjnych oraz to, że coraz więcej kobiet decyduje się na rozwój kariery zawodowej, odsuwając tym samym życie rodzinne na plan dalszy [Klimkiewicz 2010]. Ponadto kobiety zaczynają wykonywać tzw. męskie zawody, mężczyźni zaś podejmują coraz częściej pracę w zawodach przypisanych kobietom [Dzieńdziora 2017].

Statystyki, badania i raporty wskazują, że pomimo wzrastającej liczby kobiet aktywnych zawodowo i posiadających wyższe wykształcenie (w Polsce $40 \%$ dla kobiet i 25\% dla mężczyzn w 2014 roku według Ministerstwa Pracy i Polityki Społecznej) oraz inicjatyw podejmowanych przez same przedsiębiorstwa, liczba kobiet na stanowiskach kierowniczych rośnie bardzo powoli. Niniejszy artykuł poświęcony jest wymiarowi płci w miejscu pracy (gender diversity). Jego celem jest analiza sytuacji kobiet w zarządzaniu, a w szczególności zaprezentowanie barier ich awansu na stanowiska kierownicze. Podbudowę empiryczną stanowić będzie studium przypadku przeprowadzone przez autorkę w międzynarodowej korporacji.

\section{Znaczenie zwiększenia liczby kobiet na stanowiskach kierowniczych}

Priorytetem w zarządzaniu kapitałem ludzkim dla firm w Polsce i na świecie w perspektywie najbliższych 12 miesięcy staną się obszary związane z pozyskiwaniem talentów [Deloitte, Raport: Trendy HR 2018]. Tym samym rozwój wielu firm może być zagrożony z powodu narastających braków kadrowych. W warunkach, gdy ponad połowa firm w Polsce ma trudności rekrutacyjne i jedynie 24\% respondentek deklaruje ambicje zajmowania w firmie kluczowych funkcji menedżerskich [Deloitte, Raport: Pierwsze kroki na rynku pracy, 2018], warto zwrócić uwagę na to zjawisko oraz na sposoby radzenia sobie $\mathrm{z}$ takimi wyzwaniami w korporacjach międzynarodowych. Jednym z nich jest sięganie do potencjału różnorodności, a w szczególności 
do jednego z jej wymiarów - wymiaru płci jako sposobu na pozyskanie kandydatów i pracowników.

Dodatkowo korelację różnorodności ze względu na płeć zespołów zarządczych $\mathrm{z}$ rentownością przedsiębiorstw potwierdzają raporty i badania [McKinsey \& Company 2017a; 2017b; Opstrup, Villadsen 2015; Reguera-Alvarado, de Fuentes, Laffarga 2017; Sumedrea 2016]. Badacze wskazują również m.in. na pozytywny wpływ kobiet na styl zarządzania, zmierzający w kierunku demokratycznego przywództwa, zorientowanego na ludzi, na relacje interpersonalne i klimat w organizacji (cyt. za [Vrdoljak Raguž 2017, s. 275-276]) oraz przynoszą wymierną korzyść w ramach polityki CSR, sprzyjając kreowaniu pozytywnej reputacji firmy [Bear, Rahman, Post 2010].

\section{Sytuacja kobiet w zarządzaniu}

Pozyskanie kobiet do odgrywania ról kierowniczych stanowi jedno ze strategicznych wyzwań dla wielu przedsiębiorstw. Wiele z nich widzi w kompetencjach kobiet ogromny potencjał, który może przynieść im wymierne zyski, liczone nawet na poziomie 9\% PKB w 2025 [McKinsey \& Company 2007-2016]. Z drugiej strony, stereotypy dotyczące postrzegania roli kobiet powodują, że aktywność kobiet w sferze prywatnej i publicznej nie jest satysfakcjonująca. Raport McKinsey z 2017 roku (Women in the workplace) prezentuje sytuację kobiet w Ameryce, które znacznie rzadziej niż mężczyźni awansują na stanowiska kierownicze (37\%) i dyrektorskie $(33 \%)$, a na czele organizacji staje zaledwie co piąta kobieta ${ }^{1}$. Sytuacja zmienia się w zależności od sektora. Najtrudniejszą branżą dla kobiet z perspektywy możliwości awansowania jest produkcja i branża samochodowa, w której zaledwie 13\% kobiet zarządza całą firmą.

W Europie sytuacja kobiet nie jest lepsza, choć powoli ulega zmianie dzięki prowadzonym inicjatywom i działaniom realizowanym w poszczególnych krajach. Raport Komisji Europejskiej z 2011 roku pokazuje jednak, że 97\% zarządów jest kierowanych przez mężczyzn, a zaledwie jedna kobieta jest w składzie dziesięcioosobowego zarządu². W Polsce udział kobiet na rynku pracy wzrasta, głównie dzięki malejącemu bezrobociu, większej liczbie zatrudnionych kobiet na pełny etat, ale nadal nie wpływa to na zwiększenie liczby kobiet na stanowiskach kierowniczych [PwC, 2018; Spencer Stuart 2017] i w zarządach spółek, w których na kobiety przypada $12 \%$ stanowisk.

Z badań wynika, że udział kobiet (najczęściej w wieku do 35 lat) realizujących swoje kariery w postaci misji ekspatrianckich jest na niskim poziomie i wynosi ok.

${ }^{1}$ McKinsey: Women in the Workplace, s. 5: https://www.mckinsey.com/global-themes/gender-equality/women-in-the-workplace-2017, data pobrania: 03.03.2018.

${ }^{2}$ The Gender Balance in Business Leadership (2011), http://aei.pitt.edu/45615/, data pobrania: 03.03.2018. 
24\% [Brookfield Global Relocation Trends 2016]. Wiele badań wskazuje m.in. na odmienny cykl kariery [Wittenberg-Cox, Maitland 2010] oraz „szklane granice”, czyli bariery wymieniane przez kobiety w postaci m.in. braku wsparcia i braku zapewnienia mentoringu (za: [Przytuła 2014, s. 81]).

W tym miejscu należy wspomnieć o często eksponowanym zjawisku luki płacowej (gender pay gap), czyli miary nierówności w płacach kobiet i mężczyzn [Smoder, Mirosław 2016, s. 26]. Luka płacowa na stanowiskach menedżerskich w krajach należących do Unii Europejskiej w 2017 roku najniższa jest w Rumunii (5\%), Słowenii (12,4\%), Belgii (13,6\%) i Bułgarii (15,0\%). Najwyższa rozbieżność płacy notowana jest na Węgrzech (33,7\%), we Włoszech (33,5\%) i w Czechach. Polska na tym tle wypada równie słabo z $27,7 \%{ }^{3}$.

\section{Bariery awansu kobiet na stanowiska kierownicze}

Pomimo że kobiety stanowią ponad połowę populacji w większości krajów należących do Unii Europejskiej (dane Eurostatu) ${ }^{4}$ i stanowią wysoki odsetek całkowitej siły roboczej w UE, nadal nie są proporcjonalnie reprezentowane na najważniejszych stanowiskach w miejscu pracy [Komisja Europejska 2017].

Bariery awansu kobiet na stanowiska kierownicze nie są czymś zupełnie nowym, szczególnie na gruncie nauk o zarządzaniu. Liczne są raporty różnych instytucji podejmujące kwestie barier, w tym zwłaszcza stereotypów i uprzedzeń, które utrudniają kobietom sukces w życiu zawodowym i karierę kierowniczą. Znaczny wkład badawczy w tym obszarze tematycznym w polskim piśmiennictwie wniosła T. Kupczyk [2009; 2013], E. Lisowska [2001; 2007; 2008; 2009], M. Gryszko [2007; 2008; 2009]. Niemniej jednak kwestia realizacji kariery kierowniczej przez kobiety nadal jest wyzwaniem, z którym mierzą się zarówno one same, jak i przedsiębiorstwa, pomimo wielu zachodzących zmian wewnątrz i na zewnątrz organizacji wspierających i ułatwiających kobietom realizację kariery kierowniczej [Mc Kinsey \& Company 2007-2016, 2017].

Przyczyny tego zjawiska mogą być różne w poszczególnych krajach UE. Pomimo wprowadzenia regulacji prawnych wspierających kobiety w realizacji kariery (np. udogodnienia dotyczące przepisów dotyczących czasu pracy i pracy zdalnej), nadal obecne są bariery strukturalne, w tym między innymi tradycyjne role przypisywane kobietom (opieka nad dziećmi) czy brak kobiecych wzorców do naśladowania [Komisja Europejska 2011] ${ }^{5}$. Główne bariery, które powodują, że kobiety nie awansują lub odchodzą do innych organizacji, obejmują brak wzorców, wykluczenie

\footnotetext{
${ }^{3} \mathrm{http} / / /$ ec.europa.eu/eurostat/statistics-explained/index.php/Gender_pay_gap_statistics\#Gender_ pay_gap_levels, data pobrania: 10.03.2018.

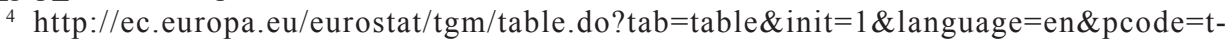
ps00011\&plugin=1, data pobrania: 10.03.2018.

${ }^{5}$ The Gender balance in business leadership, http://aei.pitt.edu/45615/1/SEC_(2011)_246.pdf, data pobrania: 10.03.2018.
} 
z nieformalnych sieci, brak wsparcia w wyższej kadrze kierowniczej, która mogłaby stworzyć możliwości awansu, brak wartości, szczególnie cenionych przez kobiety, takich jak głębokie poczucie sensu pracy i bliska współpraca z innymi [McKinsey, $2011]^{6}$.

Interesujące badania zostały przeprowadzone przez badaczy niemieckiego Uniwersytetu w Reutlingen, którzy porównali oczekiwania studentów względem przyszłej kariery zawodowej i rzeczywistość zawodową absolwentów uczelni, zarówno kobiet, jak i mężczyzn. Zaledwie 9\% studentek widziało się na najwyższym stanowisku w firmie w perspektywie od 5 do 7 lat od zakończenia studiów, żadna $(0 \%$ !) z absolwentek uczelni nie wyobrażała sobie już siebie w takiej roli po ukończeniu studiów [Mutovkina, Finckh, Gall 2016].

W Polsce wśród barier najczęściej wymienia się stereotypy [Drela 2016; Moczydłowska 2017; Vrdoljak Raguž 2017], brak zainteresowania karierą u kobiet czy jej przerwanie powodowane macierzyństwem i opieką nad dziećmi [Vrdoljak Raguž 2017].

Ważnym aspektem w kontekście barier jest również liczba dostępnych kandydatek do pracy, a szczególnie absolwentek szkół technicznych. Według GUS (Raport z 2016: Szkoły wyższe i ich finanse, s. 31) zaledwie 24,8\% kobiet kształci się na kierunkach inżynieryjno-technicznych. W raporcie za rok 2017 Kobiety na politechnikach odnotowano zwiększającą się w ciągu ostatnich 10 lat obecność kobiet na politechnikach - z 31\% do 37\%; obecnie studentki wyższych szkół technicznych stanowią blisko $14 \%$ wszystkich studiujących kobiet.

\section{Studium przypadku}

Bariery awansu kobiet na stanowiska kierownicze w korporacji międzynarodowej zostaną zaprezentowane przez autorkę na podstawie studium przypadku oraz badań empirycznych przeprowadzonych metodą wywiadów pogłębionych z kobietami na stanowiskach kierowniczych oraz uczestniczącymi w programach rozwoju talentów. Pozyskane dane zostały uzupełnione o spostrzeżenia wynikające z obserwacji uczestniczącej.

Wspomniane bariery zostaną przedstawione przez autorkę na przykładzie jednej z globalnych korporacji, działającej w Polsce. Firma X jest firmą międzynarodową, działającą w sektorze produkcyjnym. Jedną z jej wartości jest różnorodność, w tym między innymi różnorodność oparta na płci. Firma prowadzi szereg działań mających na celu promowanie wyżej wspomnianego wymiaru różnorodności, w szczególności na etapie planowania, doboru i rozwoju pracowników.

Firma X po ostatnim przeglądzie kadr, polegającym na ocenie potencjału do wykonywania ról kierowniczych w przyszłości oraz identyfikacji kadry rezerwowej,

\footnotetext{
${ }^{6}$ Unlocking the full potential of women, https://www.mckinsey.com/business-functions/organization/our-insights/unlocking-the-full-potential-of-women, data pobrania: 17.03.2018.
} 
stwierdziła brak wystarczającej liczby kobiet sukcesorów. Należy dodać, że sytuacja na rynku pracy w momencie przeprowadzania przeglądu (2017 rok) była bardzo atrakcyjna z punktu widzenia pracowników, a pracownicy firmy $\mathrm{X}$ byli doceniani za doświadczenie, umiejętności oraz kulturę pracy przez inne organizacje poszukujące kandydatów i kandydatek na stanowiska kierownicze. Kierownictwo firmy postanowiło przeprowadzić szczegółową analizę i pogłębić identyfikację potencjalnych kobiet sukcesorów przy wsparciu działu HR. Zidentyfikowano kilkanaście pracownic całej firmy, zatrudniającej ok. 800 pracowników, spośród których blisko 200 stanowiło grupę docelową, z czego $30 \%$ to były kobiety. Pracownice zostały zaproszone na indywidualne rozmowy z przedstawicielem działu HR. Celem rozmów indywidualnych było m.in.:

1) identyfikacja istniejących w organizacji barier powodujących brak wystarczającej liczby kobiet mogących objąć stanowiska kierownicze,

2) poznanie motywacji, celów zawodowych i rozwojowych kobiet,

3) weryfikacja wiedzy kobiet na temat możliwości rozwoju w firmie,

4) zainspirowanie kobiet do aktywnego rozważania opcji rozwoju (ścieżka kierownicza) $w$ ramach organizacji.

Zaproszenie i sama rozmowa została bardzo pozytywnie odebrana przez wszystkie pracownice. W większości były to osoby w przedziale wiekowym 28-35 lat, mające doświadczenie zawodowe $\mathrm{w}$ firmie $\mathrm{X}$ od 3 do 5 lat. Podczas rozmowy wszystkim uczestniczkom zadano 10 takich samych pytań. Tylko $25 \%$ pracownic zadeklarowało zainteresowanie karierą menedżerską. Co ciekawe, większość z nich przyznała, że myślała o kolejnym etapie swojej kariery zawodowej, ale nie rozmawiały na jej temat ze swoimi przełożonymi oraz nie aplikowały na ogłaszane wolne stanowiska kierownicze $\mathrm{w}$ firmie. $\mathrm{W}$ odpowiedzi na pytanie o powody wyjaśniały, że „nie są jeszcze gotowe”, „wystarczająco przygotowane”, „to jeszcze nie ten czas”, „nie mam wystarczającej wiedzy na dany temat”. Rozmówczynie wyraziły swoje zdanie na temat kultury pracy obecnego zespołu kierowniczego, w której dla $67 \%$ z nich jest za mało zorientowania na relacje i dbałości o nie, wsparcia, współpracy przy realizacji celów czy kultury prowadzenia spotkań oraz rozmów (według nich za mało dążenia do wypracowania porozumienia satysfakcjonującego wszystkie strony).

Większość pracownic wyraziła swoje obawy, czy zdołają spełnić oczekiwania firmy, oraz opowiedziała się za chęcią zachowania balansu praca-życie, bez konieczności poświęcania się pracy kosztem życia rodzinnego - „kariera tak, ale nie za wszelką cenę".

$17 \%$ kobiet nie było zainteresowanych awansem z powodów osobistych czy rodzinnych. Pytały również, czy w ten sam sposób organizacja rozmawia z pracownikami - mężczyznami.

Efekt rozmów z pracownicami uwidocznił skalę problemu. Tylko co czwarta z zaproszonych pracownic widziała swój rozwój w roli kierowniczej. Biorąc pod uwagę liczebność grupy zaproszonej do dyskusji, organizacja postanowiła podjąć 
pilnie kolejne kroki. W tym celu zostały zorganizowane warsztaty z pracownicami zmierzające do wypracowania działań mających na celu lepsze wspieranie ich oraz innych kobiet w organizacji w realizacji ich karier kierowniczych. Poruszona została również kwestia doboru oraz promowania firmy jako sprzyjającej kobietom.

\section{Wnioski}

Powyższe studium przypadku ma oczywiście swoje ograniczenia, dotyczy bowiem małej liczby pracownic, dodatkowo jest to grupa kobiet pracujących w jednej organizacji - organizacji o profilu produkcyjnym, w której zatrudniona kadra w większości posiada wykształcenie i doświadczenie techniczne, stereotypowo przypisywane mężczyznom. Niemniej jednak z rozmów z praktykami wynika, że sytuacja wygląda bardzo podobnie w firmach produkcyjnych o podobnym do firmy X profilu. Zmiana kultury pracy na zorientowaną na relacje, na współpracę, kształtowanie przyjaznej atmosfery mogłaby zachęcić kobiety do podejmowania się nowych ról kierowniczych. Kobiety bardziej niż mężczyźni oczekują również wsparcia regulującego czas pozostawania do dyspozycji pracodawcy, np. w postaci umożliwienia im pracy $w$ trybie pracy zdalnej czy w elastycznych godzinach. Jedną z bardziej oczekiwanych korzyści oferowanych przez pracodawcę byłoby zapewnienie opieki dla dzieci - w formie żłobka czy przedszkola na terenie firmy. Chętnie też pracowałyby w różnicowanym zespole, składającym się z kobiet i mężczyzn. Ważna jest dla nich również kwestia odbioru przez pozostałych pracowników w organizacji programów przeznaczonych dla pracownic.

Ze względu na konieczność zwiększenia obecności kobiet na stanowiskach kierowniczych istotne wydaje się zaangażowanie kobiet, które obecnie zajmują stanowiska kierownicze w organizacjach, na przykład przez dzielenie się doświadczeniami, zapraszanie do sieci kontaktów i mentoring. Pokazanie pozytywnych przykładów innych kobiet na stanowiskach kierowniczych, zaprezentowanie ich ścieżek rozwoju oraz sposobów łączenia ról zawodowych i prywatnych może stanowić inspiracje i zachętę dla pozostałych.

\section{Zakończenie}

Pozytywny potencjał wynikający z różnorodności płciowej zarówno został potwierdzony w badaniach naukowych jak i dostrzeżony przez praktyków. Niemniej jednak kwestia zwiększenia reprezentacji kobiet na kierowniczych i czołowych stanowiskach w organizacjach nadal pozostaje wyzwaniem dla organizacji. Dotychczasowe badania koncentrują się przede wszystkim na trudnościach, barierach w karierach kobiet w biznesie, na uwypuklaniu prawnych, kulturowych, społecznych oraz indywidualnych „szklanych sufitów, ścian i ruchomych schodów”. Przyświecające tym badaniom założenie mówi, że pozytywne zjawiska pojawią się w organizacjach, gdy 
tylko wyeliminuje się to, co negatywne. W związku z tym zajmowano się m.in. takimi problemami, jak: wprowadzanie kwot w zatrudnieniu, przełamywanie stereotypów i uprzedzeń dotyczących kobiet, zapoznawanie się z kobiecym stylem kierowania, ich reakcjami na sytuacje konfliktowe, sposobem podejmowania decyzji, strategią radzenia sobie ze stresującymi sytuacjami. Tymczasem zapobieganie procesom negatywnym nie jest wcale jednoznaczne z kreowaniem zjawisk pozytywnych. Generowanie pozytywów to coś więcej bowiem, niż zapobieganie negatywom [Glińska-Neweś 2010]. Pokazanie pozytywnych przykładów innych kobiet na stanowiskach kierowniczych, pokazanie ich karier i korzyści wynikających z korzystania $\mathrm{z}$ tego wymiaru różnorodności może stanowić inspiracje dla pozostałych kobiet i przedsiębiorstw.

Zmiany demograficzne, a w szczególności niedobór pracowników oraz pojawienie się nowych pokoleń wraz z ich nowymi potrzebami i oczekiwaniami w zakresie kształtowania karier zawodowych wskazuje, że problem jest aktualny. Warto zatem prowadzić rozważania mające na celu zminimalizowanie barier przez korzystanie z najlepszych praktyk czy kontynuowanie dyskusji w sferze nauki, zmierzających do sformułowania koncepcji, wspierających organizacje w korzystaniu z potencjału różnorodności opartej na płci.

\section{Literatura}

Bear S., Rahman N., Post C., 2010, The impact of board diversity and gender composition on CSR and firm reputation, Journal of Business Ethics, 97, s. 207-221.

Besler S., Sezerel H., 2012, Strategic diversity management initiatives: a descriptive study, Social and Behavioral Sciences, 58, s. 624-633.

Brookfield Global Relocation Trends, 2016, Global Mobility Trends Survey, New York.

Christiansen B., Sezerel H., 2013, Diversity managemnt in transcultural organizations, Global Business Perspective, 1, s. 132-143.

Deloitte, Raport: Pierwsze kroki na rynku pracy, 2018.

Deloitte, Raport: Trendy HR, 2018 www.2deloitte.com.

Drela K., 2016, Płeć jako determinanta bezrobocia, Studia Prawno-Ekonomiczne, vol. 101, s. 193-207.

Dzieńdziora J., 2017, Różnorodność karier kobiet i mężczyzn wartością współczesnych organizacji, [w:] K. Wojtaszczyk (red.), Zarządzanie różnorodnościa w teorii i praktyce, Wydawnictwo SIZ, Łódź,.

Glińska-Neweś A., 2010, Pozytywny potencjat organizacji jako prorozwojowa architektura zasobów przedsiębiorstwa, [w:] M.J. Stankiewicz (red.), Pozytywny potencjat organizacji. Wstęp do użytecznej teorii zarzadzania, Dom Organizatora, Toruń, s. 37-48.

Główny Urząd Statystyczny, www.gus.gov.pl.

Hasson Barrett N., 2012, Diversity management: The common thread binding compliance, organizational culture, and best practices, Capella University.

Klimkiewicz K., 2010, Zarządzanie różnorodnościa jako element prospołecznej polityki przedsiębiorstwa, Współczesne Zarządzanie, 2.

Kobiety na Politechnikach, 2017, Fundacja Edukacyjna Perspektywy.

Komisja Europejska, 2011, The gender balance in business leadership.

Komisja Europejska, 2017, Report on equality between women and men in the EU. 
Krawczyk-Bryłka B., Stankiewicz K., 2014, Kobiety i mężczyźni w zespole - wartość czy wyzwanie?, [w:] Sukces w zarzadzaniu kadrami. Różnorodność w zarzadzaniu kapitatem ludzkim-podejścia, metody, narzędzia. Problemy zarzadczo-psychologiczne, Prace Naukowe Uniwersytetu Ekonomicznego we Wrocławiu nr 350, s. 225-229.

Kupczyk T., 2009, Kobiety w zarządzaniu i czynniki ich sukcesów, Wydawnictwo WSH, Wrocław. Kupczyk T., 2013, Kobiety i mężczyźni w zarządzaniu, WSH we Wrocławiu, Wrocław.

Kupczyk T., Oleszkiewicz, Kubicka J., 2014, Zarządzanie różnorodnościa w dolnośląskich przedsiębiorstwach - stan wdrożenia i korzyści, [w:] Sukces w zarzadzaniu kadrami Różnorodność w zarządzaniu kapitałem ludzkim - podejścia, metody, narzędzia. Problemy zarzadczo-psychologiczne, Prace Naukowe Uniwersytetu Ekonomicznego we Wrocławiu nr 350.

McKinsey \& Company, 2007-2016, Women Matter.

McKinsey \& Company, 2015, Diversity Matters.

McKinsey \& Company, 2017a, How to accelerate gender diversity on boards in:. McKinsey Quarterly. McKinsey \& Company, 2017b, Women in boardroom.

McKinsey \& Company, 2018, Delivering through diversity.

Moczydłowska J.M., 2017, Percepcja cech i zachowań na stanowiskach kierowniczych przez pryzmat ich ptci, ZZL, 3-4/2017, IPSiS.

Mutovkina L., Finckh C., Gall M., 2016, Results and impact of global employability. Surveys regarding gender diversity conducted for German graduate study programs, International Journal of Organizational Diversity, vol. 16, Issue 3, s. 23-41.

Opstrup N., Villadsen A.R., 2015, The right mix? Gender diversity in top management teams and financial performance, Public Administration Review, vol. 75, iss. 2, s. 291-301.

Przytuła S., 2014, Zarzadzanie kadra ekspatriantów w filiach przedsiębiorstw międzynarodowych $w$ Polsce, CeDeWu.PL, Warszawa.

Reguera-Alvarado N., de Fuentes P., Laffarga J., 2017, Does board gender diversity influence financial performance? Evidence from Spain, Journal of Business Ethics, Vol. 141, Issue 2, s. 337-350.

Ricco R., Guerci M., 2014, Diversity challenge: an integrated process to bridge the implementation, Business Horizons, 57, s. 235-245.

Różnice w wynagrodzeniach kobiet i mężczyzn w Polsce, 2016, https://stat.gov.pl/files/gfx/portalinformacyjny/p1/defaultaktualnosci/5474/12/1/1/roznice_w_wynagrodzeniach_i_kobiet_i mezczyzn_w 2014.pdf, data pobrania: 02.03.2018.

Smoder A., Mirosław J., 2016, Luka placowa (gender pay gap). Pojęcie, metody pomiaru, sposoby ograniczania, Zarządzanie Zasobami Ludzkimi, Wyd. 3/4, s. 25-38.

Spencer Stuart, 2017, Poland Board Index, Edycja Polska.

Strzelczak M., 2016, Polska Karta różnorodności - polskie wyzwania i perspektywy dalszego rozwoju, Zarządzanie Zasobami Ludzkimi, Wydanie 3/4, s. 159-171.

Sumedrea S., 2016, Gender diversity and firm performance in seeking for sustainable development, Bulletin of the Transilvania University of Brasov, Series V: Economic Sciences, vol. 9, Issue 2, s. $369-384$.

Szyszka M., 2016, Aktywność zawodowa w opinii pracujacych kobiet, Annales I - Philosophy and Sociology, 41(2).

Vrdoljak Raguž I., 2017, Gender diversity in corporate boards in EU: Trends and challenges, Polish Journal of Management Studies, vol. 16, Issue 1, s. 269-279.

Wittenberg-Cox A., Maitland A., 2010, Kobiety i ich wptyw na biznes. Nowa rewolucja gospodarcza, Oficyna Wolters Kluwer Business, Warszawa.

Wróbel M., Dacko-Pikiewicz Z., 2017, Kobiece i męskie style zarządzania jako przejaw różnorodności w organizacji, [w:] K. Wojtaszczyk (red.), Zarzadzanie różnorodnościa w teorii i praktyce, Wydawnictwo SIZ, Łódź.

Wziątek-Staśko A., 2012, Diversity Management. Narzędzie skutecznego motywowania pracowników, Difin, Warszawa. 